\title{
Maternal 25-Hydroxyvitamin D and Preterm Birth in Twin Gestations
}

Lisa M. Bodnar, Ph.D., Dwight J. Rouse, M.D., Valerija Momirova, M.S., Alan M. Peaceman, M.D., Anthony Sciscione, D.O., Catherine Y. Spong, M.D., Michael W. Varner, M.D., Fergal D. Malone, M.D., Jay D. lams, M.D., Brian M. Mercer, M.D., John M. Thorp Jr., M.D., Yoram Sorokin, M.D., Marshall W. Carpenter, M.D., Julie Lo, M.D., Susan M. Ramin, M.D., and Margaret Harper, M.D. M.Sc. for the Eunice Kennedy Shriver National Institute of Child Health and Human Development (NICHD) Maternal-Fetal Medicine Units (MFMU) Network Departments of Obstetrics and Gynecology at University of Pittsburgh, Pittsburgh, PA LMB); University of Alabama at Birmingham, Birmingham, AL (D.J.R.); Northwestern University, Chicago, IL (A.M.P.); Drexel University, Philadelphia, PA (A.S.); University of Utah, Salt Lake City, UT (M.W.V); Columbia University, New York, NY (F.D.M.) ; The Ohio State University, Columbus, $\mathrm{OH}$ (J.D.I); Case Western Reserve University-MetroHealth Medical Center, Cleveland, $\mathrm{OH}$ (B.M.M); University of North Carolina, Chapel Hill, NC (J.M.T.); Wayne State University, Detroit, MI (Y.S); Brown University, Providence, RI (M.W.C.); University of Texas Southwestern Medical Center, Dallas, TX (J.L); University of Texas Health Science Center at Houston (S.M.R.); Wake Forest University Health Sciences, Winston-Salem, NC (M.H.); and The George Washington University Biostatistics Center, Washington, DC (VM); and the Eunice Kennedy Shriver National Institute of Child Health and Human Development, Bethesda, MD (CYS)

\section{Abstract}

OBJECTIVE-To assess whether there was an independent association between maternal 25hydroxyvitamin D concentrations at 24-28 weeks of gestation and preterm birth in a multicenter U.S. cohort of twin pregnancies.

METHODS-Serum samples from mothers who participated in a clinical trial of $17 \mathrm{a}$ hydroxyprogesterone caproate for the prevention of preterm birth in twin gestations (2004-2006) were assayed for 25-hydroxyvitamin D using liquid-chromatography-tandem mass spectrometry $(\mathrm{n}=211)$. Gestational age was determined early in pregnancy using a rigorous algorithm. Preterm birth was defined as delivery of the first twin or death of either twin at less than 35 weeks of gestation.

RESULTS-The mean (standard deviation) serum 25-hydroxyvitamin D was 82.7(31.5) nmol/L; $40.3 \%$ of women had 25-hydroxyvitamin Dless than $75 \mathrm{nmol} / \mathrm{L}$. Preterm birth less than 35 weeks occurred in $49.4 \%$ of mothers with 25 -hydroxyvitamin D less than $75 \mathrm{nmol} / \mathrm{L}$ compared with

(C) Copyright 2013 American College of Obstetricians and Gynecologists.

Corresponding author: Lisa Bodnar, PhD, MPH, RD Department of Epidemiology University of Pittsburgh Graduate School of Public Health 130 DeSoto Street, A742 Crabtree Hall Pittsburgh, PA 15261 412-624-9032 bodnar@edc.pitt.edu.

${ }^{*}$ For a list of other members of the NICHD MFMU, see the Appendix online at http://links.lww.com/xxx.

Dr. Spong, Associate Editor of Obstetrics \& Gynecology, was not involved in the review or decision to publish this article. Dr. Rouse, Associate Editor of Obstetrics \& Gynecology, was not involved in the review or decision to publish this article.

Financial Disclosure: The authors did not report any potential conflicts of interest.

This is a PDF file of an unedited manuscript that has been accepted for publication. As a service to our customers we are providing this early version of the manuscript. The manuscript will undergo copyediting, typesetting, and review of the resulting proof before it is published in its final citable form. Please note that during the production process errors may be discovered which could affect the content, and all legal disclaimers that apply to the journal pertain. 
$26.2 \%$ among those with 25 -hydroxyvitamin D $75 \mathrm{nmol} / \mathrm{L}$ or more $(P<.001)$. After adjustment for maternal race and ethnicity, study site, parity, prepregnancy body mass index, season, marital status, education, gestational age at blood sampling, smoking status and $17 \mathrm{a}$ hydroxyprogesterone caproate treatment, maternal 25 -hydroxyvitamin D $75 \mathrm{nmol} / \mathrm{L}$ or more was associated with a $60 \%$ reduction in the odds of preterm birth compared with less than $75 \mathrm{nmol} / \mathrm{L}$ (adjusted odds ratio[OR] 0.4, 95\% confidence interval [CI] 0.2-0.8). A similar protective association was observed when studying preterm birth less than 32 weeks (OR 0.2, 95\% CI 0.10.6 ) and after confounder adjustment.

CONCLUSIONS-Late second trimester maternal 25-hydroxyvitamin D less than $75 \mathrm{nmol} / \mathrm{L}$ is associated with an increase in the risk of preterm birth in this cohort of twin pregnancies.

\section{Introduction}

The health-promoting role of vitamin D during pregnancy is contentiously debated (1-4). Optimal maternal 25-hydroxyvitamin D concentrations are not known. Nearly one in three pregnant women in the United States has serum 25-hydroxyvitamin D less than $50 \mathrm{nmol} / \mathrm{L}$ (5), which experts agree increases the risks of bone-related disease for mothers and fetuses $(3,6)$. Approximately two in three pregnant women have serum 25 -hydroxyvitamin D less than $75 \mathrm{nmol} / \mathrm{L}$ (5), concentrations associated with cancer, diabetes, cardiovascular disease, autoimmune disorders, and other adverse health outcomes in nonpregnant adults $(7,8)$.

It remains unclear whether vitamin D deficiency poses risks for nonskeletal outcomes during pregnancy $(9,10)$. The ability of maternal decidual cells to convert 25 -hydroxyvitamin $\mathrm{D}$ to 1,25 -dihydroxyvitamin $\mathrm{D}$, the hormonally active form of the vitamin, as well as the presence of vitamin D receptors on the placenta (11) highlight a potentially important role for vitamin $\mathrm{D}$ in pregnancy outcomes, including spontaneous preterm birth. 1,25-dihydroxyvitamin D has immunomodulatory and antiinflammatory properties and regulates key genes for successful implantation (12), yet few research studies have explored the relation between 25-hydroxyvitamin D and preterm birth (13-15), and none have examined this association in twin pregnancies. Mothers carrying twins have greater nutrient demands (16) and dramatically higher rates of preterm birth than singleton gestations (17). Research into the role of maternal vitamin D deficiency, a common, modifiable factor, in poor outcomes in twin gestations may help improve maternal and child health in these vulnerable pregnancies.

Our objective was to assess the association between maternal 25-hydroxyvitamin D concentrations at 24-28 weeks of gestation and preterm birth in a multicenter U.S. cohort of twin pregnancies.

\section{Materials and Methods}

This is a secondary analysis of data and samples from a randomized, double-blinded, placebo-controlled trial of 17 a-hydroxyprogesterone caproate for the prevention of preterm birth in twin gestations (2004-2006). Details of the study have been published previously (18). Briefly, women carrying twin pregnancies who were 16 weeks to 20 weeks 3 days of gestation were recruited from 14 study centers in the United States after providing informed, written consent. They were randomized to weekly injections of either $17 \mathrm{a}$ -

hydroxyprogesterone caproate or placebo until 34 weeks and 6 days of gestation or delivery, whichever occurred first. Medical charts were abstracted by trained, certified personnel to ascertain data on antepartum and intrapartum events, obstetrical interventions, and neonatal outcomes. The study was approved by the institutional review boards at each clinical site and at the data coordinating center. 
An ancillary study to the clinical trial to investigate the pharmacokinetics and pharmacodynamics of 17 a-hydroxyprogesterone caproate began with approximately 1 year left in recruitment. The participants of the ancillary study provided a nonfasting blood sample at 24-28 weeks of gestation. These samples were centrifuged and frozen at $-80^{\circ} \mathrm{C}$ for future analysis. Serum samples were analyzed in a single batch for 25 -hydroxyvitamin $D$ [25-hydroxyvitamin $\mathrm{D}_{2}+25$-hydroxyvitamin $\mathrm{D}_{3}$ ] using liquid-chromatography-tandem mass spectrometry (19). The assay had a lower detection limit of $1 \mathrm{ng} / \mathrm{mL}$ and no upper limit. The intra-assay coefficient of variation was $8.2 \%$ and $5.9 \%$ for 25 -hydroxyvitamin $\mathrm{D}_{2}$ and 25-hydroxyvitamin $\mathrm{D}_{3}$, respectively. There is no universally acceptable definition of vitamin $\mathrm{D}$ deficiency. Therefore, we explored 25 -hydroxyvitamin $\mathrm{D}$ as a continuous variable, as a binary variable (less than $75 \mathrm{nmol} / \mathrm{L}$ compared with $75 \mathrm{nmol} / \mathrm{L}$ or more) (6), and categorized based on distribution quartiles.

Gestational age was determined according to an algorithm on the basis of the last menstrual period and the results of ultrasonography of the larger fetus for women who conceived spontaneously (20). For women who conceived by in vitro fertilization, the duration of gestation was calculated on the basis of the date of embryo transfer and the age of the embryos when transferred (18). The primary outcome for the clinical trial was delivery of the first twin or death of either twin at less than 35 weeks gestation. For the purposes of this analysis, we have termed that outcome "preterm birth" and analyzed by pregnancy, not individual infant. Spontaneous preterm birth was defined as a preterm birth at less than 35 weeks occurring after preterm labor with intact membranes or preterm prelabor rupture of the fetal membranes. Prespecified criteria encoded in the study manual of operations were used to define whether the birth was indicated or spontaneous, and this distinction was made prior to the measurement of 25-hydroxyvitamin D.

Because 17 a-hydroxyprogesterone caproate had no significant effect on the occurrence of preterm delivery (18), all women were included in this secondary analysis. Continuous variables were compared using the Wilcoxon rank sum test. Categorical variables were analyzed using chi-square or Fisher exact test, where appropriate. Multivariable logistic regression models were used to quantify the association between maternal 25hydroxyvitamin $\mathrm{D}$ and preterm birth after adjusting for prepregnancy body mass index (BMI), race and ethnicity, maternal age, parity, smoking, marital status, education, study site, gestational age at blood draw, 17 a-hydroxyprogesterone caproate treatment and season at blood draw (confounders identified using theory-based causal diagrams (21)). Nominal two-tailed $P$ values were reported and no adjustments were made for multiple comparisons. $P<.05$ was considered significant. Statistical analysis was performed using SAS software (SAS Institute, Cary, NC).

\section{Results}

Of the 661 women enrolled in the randomized trial, 211 (31.9\%) had a serum sample drawn at 24-28 weeks for serum 25-hydroxyvitamin D measurement. A total of 20 mothers in the parent study who were eligible for the ancillary study delivered before 24 weeks.

Participants who had serum available for 25-hydroxyvitamin D measurement were slightly more likely than women without stored serum to be lean and better educated, but there were no significant differences in any other characteristic (Table 1). In the sample with 25-

hydroxyvitamin D assayed, no total 25-hydroxyvitamin D concentrations fell below the detectable range. There were 75 cases of preterm birth (one of which qualified because of a stillbirth) at less than 35 weeks (35.6\%), including 50 cases of spontaneous preterm birth at less than 35 weeks (50/186 deliveries that were not indicated preterm birth less than 35 weeks, 26.9\%) and 25 patients were indicated deliveries prior to 35 weeks. Twenty-five women (11.8\%) delivered before 32 weeks, including 10 women who delivered before 30 
weeks. Of the 117 parous patients in this analysis, 16 had a previous delivery less than 35 weeks of gestation $(13.7 \%)$.

The mean (standard deviation, SD) serum 25-hydroxyvitamin D was $82.7( \pm 31.5) \mathrm{nmol} / \mathrm{L}$, and the median was $85.7 \mathrm{nmol} / \mathrm{L} ; 40.3 \%$ of women had 25-hydroxyvitamin D less than 75 $\mathrm{nmol} / \mathrm{L}$, and $18.0 \%$ less than $50 \mathrm{nmol} / \mathrm{L}$. Mothers with serum 25 -hydroxyvitamin $\mathrm{D}$ less than $75 \mathrm{nmol} / \mathrm{L}$ were more likely than mothers with 25 -hydroxyvitamin D $75 \mathrm{nmol} / \mathrm{L}$ or more to be non-Hispanic black or Hispanic, young, unmarried, obese before pregnancy, and to have less than a high school education and delivered earlier (Table 2). The median 25hydroxyvitamin D concentrations among mothers identifying their race and ethnicity as nonHispanic white, non-Hispanic black, and Hispanic or other were $96.6 \mathrm{nmol} / \mathrm{L}, 50.1 \mathrm{nmol} / \mathrm{L}$, and $73.9 \mathrm{nmol} / \mathrm{L}$, respectively.

Preterm birth less than 35 weeks occurred in $49.4 \%$ of mothers with 25 -hydroxyvitamin D less than $75 \mathrm{nmol} / \mathrm{L}$ compared with $26.2 \%$ among those with 25 -hydroxyvitamin D 75 $\mathrm{nmol} / \mathrm{L}$ or more (Table 3, $P<.001$ ). Maternal serum 25 -hydroxyvitamin D $75 \mathrm{nmol} / \mathrm{L}$ or more was associated with a $60 \%$ reduction in the odds of preterm birth compared with less than $75 \mathrm{nmol} / \mathrm{L}$. This association remained after adjustment for maternal race and ethnicity, study site, parity, prepregnancy BMI, smoking status, marital status, education, 17 ahydroxyprogesterone caproate treatment and season at blood sampling. When 25hydroxyvitamin D was studied as a continuous variable, every $31.5 \mathrm{nmol} / \mathrm{L}$ (1-SD) increase in 25-hydroxyvitamin D was associated with a 50\% decrease in the odds of preterm birth at less than 35 weeks. In quartile analysis, women with 25-hydroxyvitamin D in the highest fourth of the distribution had a reduced odds of preterm birth less than 35 weeks compared with those in the bottom fourth (Table 3).

Results were similar when we limited analysis to spontaneous preterm birth less than 35 weeks. Gravida with serum 25 -hydroxyvitamin D less than $75 \mathrm{nmol} / \mathrm{L}$ had more spontaneous preterm birth $(29 / 72 ; 40.3 \%)$ than women with 25 -hydroxyvitamin D $75 \mathrm{nmol} /$ $\mathrm{L}$ or more $(21 / 114 ; 18.4 \%, P<.01)$. The adjusted OR $(95 \% \mathrm{CI})$ for spontaneous preterm birth associated with a 1-SD increase in 25-hydroxyvitamin $\mathrm{D}$ was $0.5(0.3-0.9)$. There were too few cases of indicated preterm birth less than 35 weeks $(n=25)$ to perform statistical modeling. However, in bivariate analyses women with serum 25-hydroxyvitamin D less than $75 \mathrm{nmol} / \mathrm{L}$ were more likely to have indicated preterm birth less than 35 weeks than mothers with 25 -hydroxyvitamin D $75 \mathrm{nmol} /$ Lor more (23.2\% compared with $11.4 \%, P<.05$ ).

Maternal 25-hydroxyvitamin D concentration was also negatively associated with preterm birth less than 32 weeks (Table 4). Compared with 25-hydroxyvitamin D less than $75 \mathrm{nmol} /$ $\mathrm{L}$, serum 25 -hydroxyvitamin $\mathrm{D} 75 \mathrm{nmol} / \mathrm{L}$ or more was associated with an $80 \%$ reduction in risk of preterm birth less than 32 weeks, after adjustment for confounders. A 1-SD increase in 25 -hydroxyvitamin D was associated with a $60 \%$ decrease in the likelihood of preterm birth less than 32 weeks. None of these associations differed by maternal race and ethnicity.

\section{Discussion}

In this multicenter U.S. cohort of women carrying twins, we observed that serum vitamin D measured at 24-28 weeks was inversely associated with the risk of preterm birth at less than 35 weeks and less than 32 weeks and spontaneous preterm birth less than 35 weeks, even after adjusting for covariates such as prepregnancy BMI, race and ethnicity, and season.

Little is known about maternal vitamin D status in relation to risk of preterm birth in twin pregnancies. In a trial of 504 mothers carrying singleton pregnancies who were randomized to receive 400,2000 or 4000 international unit vitamin $\mathrm{D}_{3}$ per day from 12-16 weeks to delivery, there was no difference in rates of preterm birth without preeclampsia by treatment 
group (22). These authors reported that mothers with 25-hydroxyvitamin D less than 80 $\mathrm{nmol} / \mathrm{L}$ before delivery were more likely to deliver preterm without preeclampsia than mothers with higher concentrations, but this finding may be explained by reverse causality. Using 131 cases of preterm birth less than 35 weeks and 134 term controls, all of whom were singleton pregnancies with a history of preterm birth, from a U.S. multicenter randomized trial of omega- 3 fatty acid supplementation, investigators observed no relationship between 25-hydroxyvitamin D at 12-16 weeks or 25-28 weeks and recurrent preterm birth (13). Our findings may differ because all women in this population had a history of preterm birth and received weekly injections of 17 a-hydroxyprogesterone caproate throughout pregnancy. Researchers using a Canadian cohort of 221 singleton pregnancies at high risk of preeclampsia observed no association between 25-

hydroxyvitamin D at 19 weeks and preterm birth less than 37 weeks (14). In a sample of 884 human immunodeficiency virus-infected African mothers carrying singletons, there was no association between 25-hydroxyvitamin D at a mean (SD) of 20 (4) weeks and risk of preterm birth at less than 37 weeks or less than 34 weeks after controlling for multivitamin supplementation, age, enrollment CD4 cell count, and human immunodeficiency virusstage (15). Similarly, gestational age (rather than preterm birth) was studied in three other singleton gestation cohorts, and results were mixed $(17,23,24)$.

Our finding that poor vitamin D status is associated with early preterm birth suggests that the anti-inflammatory and immunomodulating roles of vitamin D may be relevant(12). Vitamin D regulates uterine-natural killer cells and other immune cells in vitro by suppressing inflammatory cytokine production (25). A similar impact of vitamin D on cultured trophoblastic cells has been observed (26), which implies a general antiinflammatory role in pregnancy. Vitamin D promotes innate immune responses in monocytes by stimulating antimicrobial activity (27). In addition, vitamin D regulates genes critical for successful implantation, including calbindin-D $9 K$ and $H O X A$ through intracrine or paracrine pathways (12).

The demands for micronutrients including vitamin $\mathrm{D}$ in twin pregnancies are believed to be higher than those for singleton pregnancies $(16,28)$, yet a lack of data to inform nutrient needs in twin pregnancy has resulted in the same recommended dietary allowance (600 international unit vitamin D per day) for singleton and multiple pregnancies (3). We therefore did not expect to observe a higher median 25-hydroxyvitamin D in this multicenter U.S. cohort of twin pregnancies than what has been reported in other U.S. singleton samples (29-31), including in a nationally representative group of pregnant mothers $(74.4 \mathrm{nmol} / \mathrm{L}$ for non-Hispanic whites; $33.2 \mathrm{nmol} / \mathrm{L}$ for non-Hispanic blacks, and $54.0 \mathrm{nmol} / \mathrm{L}$ for MexicanAmericans (5). The higher median 25-hydroxyvitamin D concentrations may be due to differences in intake of vitamin D through supplements or diet, or to our inclusion of women from the southern United States, who may be exposed to greater amounts of solar radiation. Unfortunately, we lacked data on vitamin D intake and sunlight exposure to evaluate the contributing factors. However, characteristics such as race and ethnicity and obesity, which are typically associated with vitamin D during pregnancy, were also related in our cohort.

Limitations of our study warrant comment. We used a convenience sample of mothers who provided a blood sample at 24-28 weeks as part of the ancillary study. Our results may be biased if vitamin $\mathrm{D}$ concentrations affected selection into the ancillary study. For instance, if vitamin D deficiency caused preterm birth, then excluding the 20 mothers in the parent study who delivered before 24 weeks (and therefore could not participate in the ancillary study) would lead to an underestimation of effects. Although we adjusted for many known factors to be associated with both 25-hydroxyvitamin D and preterm birth, unmeasured confounding by intake of other micronutrients, physical activity, and maternal genotype may have biased our findings, and imperfect measurement of prepregnancy obesity using self-reported data 
and socioeconomic position using education and marital status may have led to residual confounding. Additionally, only one blood sample before the third trimester was obtained in the parent study, so we could not evaluate other windows of vitamin D exposure. Strengths of our study include measurement of 25-hydroxyvitamin D before the clinical onset of preterm delivery using liquid chromatography-tandem mass spectrometry (the gold standard method), and estimation of gestational age in pregnancy based on a well-established algorithm (18).

Preterm delivery is a major contributor to the excess infant morbidity and mortality in twin pregnancies (32), and identifying modifiable risk factors for preterm birth in twins is a major public health priority (33). Observational studies beginning early in pregnancy of large, representative cohorts of mothers carrying multiple fetuses are the logical next step to assess whether maternal 25 -hydroxyvitamin D concentrations are consistently associated with preterm birth. If these results are replicated, randomized trials of vitamin D supplementation may be warranted.

\section{Acknowledgments}

Supported by NIH grant R01 HD056999 (PI: Bodnar) and by grants from the Eunice Kennedy Shriver National Institute of Child Health and Human Development (NICHD) [HD27869, HD21410, HD40512, HD34136, HD34208, HD40485, HD27915, HD40544, HD40560, HD27917, HD40500, HD34116, HD40545, HD27860, HD36801] and the National Center for Research Resources [M01 RR00080, UL1 RR024989], and its contents do not necessarily represent the official view of NICHD, NHLBI, NCRR or NIH.

The authors thank Margaret Cotroneo, R.N. and Allison T. Northen, M.S.N., R.N. for protocol development and coordination between clinical research centers; Elizabeth Thom, $\mathrm{PhD}$ for protocol and data management and statistical analysis; and Steve N Caritis, MD for protocol development and oversight.

\section{Appendix: List of Centers in the NICHD MFMU Network}

In addition to the authors, other members of the Eunice Kennedy Shriver National Institute of Child

Health and Human Development Maternal-Fetal Medicine Units Network are as follows:

University of Pittsburgh - S. Caritis, E. Daugherty, M. Cotroneo, H. Simhan

University of Alabama at Birmingham - W. Andrews, J. Sheppard, A. Northen

Northwestern University - M. Dinsmoor (NorthShore University HealthSystem), G. Mallett, P. Simon, M. Huntley, M. Ramos

Drexel University - M. Hoffman, S. Wilson, C. Tocci, M. Lake, M. Talucci

University of Utah - K. Anderson, F. Porter (LDS Hospital), A. Guzman (McKay-Dee Hospital Center), K. Jolley (Utah Valley Regional Medical Center), S. Quinn (LDS Hospital)

Columbia University - R. Berkowitz, S. South, L. Paley, S. Bousleiman, V. Carmona

The Ohio State University -F. Johnson, C. Latimer

Case Western Reserve University - C. Milluzzi, C. Heggie, H. Ehrenberg, B. Stetzer, A. Merlino

University of North Carolina at Chapel Hill - K. Boggess, K. Dorman, S. Timlin 
Wayne State University — G. Norman, C. Sudz, S. Blackwell

Brown University - D. Allard

University of Texas Southwestern Medical Center, Dallas — K. Leveno, L. Moseley

University of Texas Health Science Center at Houston - D. Soebbing-Cross, J. Martinez, B. Glenn-Cole, L. Gilstrap

Wake Forest University Health Sciences - P. Meis, M. Swain, K. Johnson, K. Lanier, C. Leftwich

The George Washington University Biostatistics Center - E. Thom, A. Braga, E. Cardenas, L. Leuchtenburg

Eunice Kennedy Shriver National Institute of Child Health and Human Development — S. Tolivaisa

MFMU Network Steering Committee Chair (University of Texas Medical Center, Galveston, $T X)$ - G. Anderson, M.D

\section{References}

1. Hollis BW, Wagner CL. Vitamin D requirements and supplementation during pregnancy. Current opinion in endocrinology, diabetes, and obesity. 2011; 18(6):371-5.

2. ACOG. Vitamin D: screening and supplementation during pregnancy. Committee Opinion No. 495. Obstet Gynecol. 2011; 118:197-8. [PubMed: 21691184]

3. IOM. Dietary Reference Intakes for Calcium and Vitamin D. Ross, AC.; Taylor, CL.; Yaktine, AL.; Del Valle, HB., editors. National Academy Press; Washington, D.C.: 2010.

4. Heaney RP, Holick MF. Why the IOM recommendations for vitamin D are deficient. Journal of bone and mineral research : the official journal of the American Society for Bone and Mineral Research. 2011; 26(3):455-7. [PubMed: 21337617]

5. Looker AC, Pfeiffer CM, Lacher DA, Schleicher RL, Picciano MF, Yetley EA. Serum 25hydroxyvitamin D status of the US population: 1988-1994 compared with 2000-2004. Am J Clin Nutr. 2008; 88(6):1519-27. [PubMed: 19064511]

6. Holick MF, Binkley NC, Bischoff-Ferrari HA, Gordon CM, Hanley DA, Heaney RP, Murad MH, Weaver CM. Evaluation, treatment, and prevention of vitamin D deficiency: an Endocrine Society clinical practice guideline. J Clin Endocrinol Metab. 2011; 96(7):1911. [PubMed: 21646368]

7. Heaney RP. Assessing vitamin D status. Current opinion in clinical nutrition and metabolic care. 2011; 14(5):440-4. [PubMed: 21832900]

8. Holick MF. Vitamin D deficiency. N Engl J Med. 2007; 357(3):266-81. [PubMed: 17634462]

9. Bodnar LM, Simhan HN. Vitamin D may be a link to black-white disparities in adverse birth outcomes. Obstet Gynecol Surv. 2010; 65(4):273-84. [PubMed: 20403218]

10. Brannon PM, Picciano MF. Vitamin D in pregnancy and lactation in humans. Annual Review of Nutrition. 2011; 31:89-115.

11. Hewison M, Burke F, Evans KN, Lammas DA, Sansom DM, Liu P, Modlin RL, Adams JS. Extrarenal 25-hydroxyvitamin D3-1alpha-hydroxylase in human health and disease. J Steroid Biochem Mol Biol. 2007; 103(3-5):316-21. [PubMed: 17368179]

12. Liu NQ, Hewison M. Vitamin D, the placenta and pregnancy. Archives of biochemistry and biophysics. 2012; 523(1):37-47. [PubMed: 22155151]

13. Thorp JM, Camargo CA, McGee PL, Harper M, Klebanoff MA, Sorokin Y, Varner MW, Wapner RJ, Caritis SN, Iams JD, Carpenter MW, Peaceman AM, Mercer BM, Sciscione A, Rouse DJ, Ramin SM, Anderson GB. Vitamin D status and recurrent preterm birth: a nested case control study in high-risk women. BJOG. 2012; 119(13):1617-23. [PubMed: 23078336] 
14. Shand AW, Nassar N, Von Dadelszen P, Innis SM, Green TJ. Maternal vitamin D status in pregnancy and adverse pregnancy outcomes in a group at high risk for pre-eclampsia. BJOG. 2010; 117(13):1593-8. [PubMed: 21040394]

15. Mehta S, Hunter DJ, Mugusi FM, Spiegelman D, Manji KP, Giovannucci EL, Hertzmark E, Msamanga GI, Fawzi WW. Perinatal outcomes, including mother-to-child transmission of HIV, and child mortality and their association with maternal vitamin D status in Tanzania. J Infect Dis. 2009; 200(7):1022-30. [PubMed: 19673647]

16. Goodnight W, Newman R. Optimal nutrition for improved twin pregnancy outcome. Obstetrics and Gynecology. 2009; 114(5):1121-34. [PubMed: 20168116]

17. Scholl TO, Chen X. Vitamin D intake during pregnancy: association with maternal characteristics and infant birth weight. Early human development. 2009; 85(4):231-4. [PubMed: 19008055]

18. Rouse DJ, Caritis SN, Peaceman AM, Sciscione A, Thom EA, Spong CY, Varner M, Malone F, Iams JD, Mercer BM, Thorp J, Sorokin Y, Carpenter M, Lo J, Ramin S, Harper M, Anderson G. A trial of 17 alpha-hydroxyprogesterone caproate to prevent prematurity in twins. New England Journal of Medicine. 2007; 357(5):454-61. [PubMed: 17671253]

19. Holick MF, Siris ES, Binkley N, Beard MK, Khan A, Katzer JT, Petruschke RA, Chen E, de Papp AE. Prevalence of Vitamin D inadequacy among postmenopausal North American women receiving osteoporosis therapy. J Clin Endocrinol Metab. 2005; 90(6):3215-24. [PubMed: 15797954]

20. Carey JC, Klebanoff MA, Hauth JC, Hillier SL, Thom EA, Ernest JM, Heine RP, Nugent RP, Fischer ML, Leveno KJ, Wapner R, Varner M. Metronidazole to prevent preterm delivery in pregnant women with asymptomatic bacterial vaginosis. National Institute of Child Health and Human Development Network of Maternal-Fetal Medicine Units. The New England journal of medicine. 2000; 342(8):534-40. [PubMed: 10684911]

21. Hernan MA, Hernandez-Diaz S, Werler MM, Mitchell AA. Causal knowledge as a prerequisite for confounding evaluation: an application to birth defects epidemiology. American Journal of Epidemiology. 2002; 155:176-184. [PubMed: 11790682]

22. Wagner CL, McNeil RB, Johnson DD, Hulsey TC, Ebeling M, Robinson C, Hamilton SA, Hollis BW. Health characteristics and outcomes of two randomized vitamin D supplementation trials during pregnancy: A combined analysis. The Journal of steroid biochemistry and molecular biology. 2013

23. Morley R, Carlin JB, Pasco JA, Wark JD. Maternal 25-hydroxyvitamin D and parathyroid hormone concentrations and offspring birth size. J Clin Endocrinol Metab. 2006; 91(3):906-12. [PubMed: 16352684]

24. Moller UK, Streym S, Heickendorff L, Mosekilde L, Rejnmark L. Effects of 25OHD concentrations on chances of pregnancy and pregnancy outcomes: a cohort study in healthy Danish women. European journal of clinical nutrition. 2012; 66(7):862-8. [PubMed: 22378226]

25. Evans KN, Nguyen L, Chan J, Innes BA, Bulmer JN, Kilby MD, Hewison M. Effects of 25hydroxyvitamin D3 and 1,25-dihydroxyvitamin D3 on cytokine production by human. Biol Reprod. 2006; 75(6):816-22. [PubMed: 16957024]

26. Diaz L, Noyola-Martinez N, Barrera D, Hernandez G, Avila E, Halhali A, Larrea F. Calcitriol inhibits TNF-alpha-induced inflammatory cytokines in human trophoblasts. J Reprod Immunol. 2009; 81(1):17-24. [PubMed: 19501915]

27. Adams JS, Hewison M. Unexpected actions of vitamin D: new perspectives on the regulation of innate and adaptive immunity. Nat Clin Pract Endocrinol Metab. 2008; 4(2):80-90. [PubMed: 18212810]

28. Roem K. Nutritional management of multiple pregnancies. Twin research : the official journal of the International Society for Twin Studies. 2003; 6(6):514-9. [PubMed: 14965462]

29. Bodnar LM, Krohn MA, Simhan HN. Maternal vitamin D deficiency is associated with bacterial vaginosis in the first trimester of pregnancy. J Nutr. 2009; 139(6):1157-61. [PubMed: 19357214]

30. Bodnar LM, Simhan HN, Powers RW, Frank MP, Cooperstein E, Roberts JM. High prevalence of vitamin $\mathrm{D}$ insufficiency in black and white pregnant women residing in the northern United States and their neonates. J Nutr. 2007; 137(2):447-52. [PubMed: 17237325] 
31. Johnson DD, Wagner CL, Hulsey TC, McNeil RB, Ebeling M, Hollis BW. Vitamin D deficiency and insufficiency is common during pregnancy. Am J Perinatol. 2011; 28(1):7-12. [PubMed: 20640974]

32. Martin, JA.; Hamilton, BE.; Ventura, SJ.; Osterman, MJK.; Kirmeyer, S.; Mathews, TJ.; Wilson, EC. National vital statistics reports. Vol. vol 60. National Center for Health Statistics; Hyattsville, MD: 2011. Births: Final data for 2009.

33. IOM. Preterm birth: causes, consequences, and prevention. Behrman, R.; Stith Butler, A., editors. National Academy of Sciences; Washington, D.C.: 2006. 
Table 1

Characteristics of Participants From the Parent Clinical TrialWith and Without Available Serum For Assay of 25-Hydroxyvitamin D.

\begin{tabular}{|c|c|c|c|}
\hline Characteristic & $\begin{array}{c}\text { Women With } \\
\text { Available Serumfor } \\
\text { 25-Hydroxyvitamin } \\
\text { D } \\
\mathbf{n}=\mathbf{2 1 1}\end{array}$ & $\begin{array}{c}\text { WomenWithout } \\
\text { Available Serum for } \\
\text { 25-Hydroxyvitamin D } \\
\text { n= 450* }\end{array}$ & $P$ \\
\hline Maternal race and ethnicity & & & 0.36 \\
\hline Non-Hispanic white & $131(62.1)$ & $255(56.7)$ & \\
\hline Non-Hispanic black & $47(22.3)$ & $107(23.8)$ & \\
\hline Hispanic or other & 33 (15.6) & 88 (19.5) & \\
\hline Maternal age, y & & & 0.62 \\
\hline Younger than 20 & $11(5.5)$ & $32(7.5)$ & \\
\hline $20-29$ & $84(42.0)$ & $180(42.4)$ & \\
\hline 30 or older & $105(52.5)$ & $213(50.1)$ & \\
\hline Marital status & & & 0.96 \\
\hline Married or living with partner & $157(74.4)$ & $334(74.2)$ & \\
\hline Not married & $54(25.6)$ & $116(25.8)$ & \\
\hline Maternal education & & & 0.04 \\
\hline Less than high school & $32(15.2)$ & $72(16.0)$ & \\
\hline High school or equivalent & $32(15.2)$ & $105(23.3)$ & \\
\hline Greater than high school & $147(69.7)$ & $273(60.7)$ & \\
\hline Parity & & & 0.93 \\
\hline 0 & $94(44.5)$ & $202(44.9)$ & \\
\hline 1 or more & $117(55.5)$ & $248(55.1)$ & \\
\hline Smoking status & & & 0.27 \\
\hline Smoker & $18(8.5)$ & $51(11.3)$ & \\
\hline Nonsmoker & $193(91.5)$ & $399(88.7)$ & \\
\hline Prepregnancy BMI, $\mathrm{kg} / \mathrm{m}^{2}$ & & & 0.02 \\
\hline Less than 25 & $95(45.5)$ & $215(49.2)$ & \\
\hline $25-29.9$ & $64(30.6)$ & $92(21.1)$ & \\
\hline 30 or more & $50(23.9)$ & $130(29.7)$ & \\
\hline $\begin{array}{l}\text { Gestational age at blood draw, } \\
\text { wk }\end{array}$ & $26.2( \pm 1.1)$ & - & - \\
\hline Season of blood draw & & - & - \\
\hline Winter & $56(26.7)$ & & \\
\hline Spring & $67(31.9)$ & & \\
\hline Summer & 37 (17.6) & & \\
\hline Fall & $50(23.8)$ & & \\
\hline Latitude of study site & & & 0.79 \\
\hline $40^{\circ} \mathrm{N}$ to $42^{\circ} \mathrm{N}$ & $156(73.9)$ & $337(74.9)$ & \\
\hline $30^{\circ} \mathrm{N}$ to $36^{\circ} \mathrm{N}$ & $55(26.1)$ & $113(26.1)$ & \\
\hline $\begin{array}{l}\text { 17a-hydroxyprogesterone } \\
\text { caproatetreatment group }\end{array}$ & $93(44.1)$ & $234(52.0)$ & 0.06 \\
\hline
\end{tabular}




\begin{tabular}{|c|c|c|c|}
\hline Characteristic & $\begin{array}{c}\text { Women With } \\
\text { Available Serumfor } \\
\text { 25-Hydroxyvitamin } \\
\text { D } \\
\qquad=211\end{array}$ & $\begin{array}{c}\text { WomenWithout } \\
\text { Available Serum for } \\
\text { 25-Hydroxyvitamin D } \\
\text { n=450* }\end{array}$ & $P$ \\
\hline Pregnancy achieved using & & & 0.58 \\
\hline $\begin{array}{l}\text { assisted reproductive } \\
\text { technology }\end{array}$ & $47(22.3)$ & $109(24.2)$ & \\
\hline Infant birthweight, $\mathrm{g}$ & $2182( \pm 510)$ & $2084( \pm 627)$ & 0.16 \\
\hline Gestational age at delivery, wk & $35.2( \pm 2.8)$ & $34.4( \pm 4.2)$ & 0.32 \\
\hline Birth prior to 35 weeks & $75( \pm 35.6)$ & $183( \pm 41.2)$ & 0.17 \\
\hline $\begin{array}{l}\text { Spontaneous birth less than } 35 \\
\text { weeks }^{\dagger}\end{array}$ & $50(26.9)$ & $137(34.4)$ & 0.07 \\
\hline
\end{tabular}

BMI, body mass index.

Data presented as n $(\%)$ or mean ( \pm standard deviation) unless otherwise specified.

Missing data on covariates were as follows: $n=36$ missing maternal age; $n=15$ missing prepregnancy BMI; $n=6$ missing birth outcome data due to loss to follow-up.

${ }^{\dagger}$ Out of those who were not indicated deliveries at less than 35 weeks. 
Table 2

Maternal Characteristics in Association With Serum 25-Hydroxyvitamin D Concentrations at 24-28 Weeks.

\begin{tabular}{|c|c|c|c|}
\hline Characteristic & $\begin{array}{c}\text { Less Than } 75 \\
\text { nmol/L } \\
\mathbf{n}=\mathbf{8 5}\end{array}$ & $\begin{array}{c}75 \mathrm{nmol} / \mathrm{L} \text { or } \\
\text { More } \\
\mathrm{n}=126\end{array}$ & $P$ \\
\hline Maternal race and ethnicity & & & $<0.001$ \\
\hline Non-Hispanic white & $26(30.6)$ & $105(83.3)$ & \\
\hline Non-Hispanic black & $40(47.1)$ & $7(5.6)$ & \\
\hline Hispanic or other & $19(22.3)$ & $14(11.1)$ & \\
\hline Maternal age, y & & & $<0.001$ \\
\hline Younger than 20 & $9(11.4)$ & $2(1.7)$ & \\
\hline $20-29$ & $43(54.4)$ & $41(33.9)$ & \\
\hline 30 or older & $27(34.2)$ & $78(64.5)$ & \\
\hline Marital status & & & $<0.001$ \\
\hline Married or living with partner & $48(56.5)$ & $109(86.5)$ & \\
\hline Not married & $37(43.5)$ & $17(13.5)$ & \\
\hline Maternal education & & & $<0.001$ \\
\hline Less than high school & $20(23.5)$ & $12(9.5)$ & \\
\hline High school or equivalent & $18(21.2)$ & $14(11.1)$ & \\
\hline Greater than high school & $47(55.3)$ & $100(79.4)$ & \\
\hline Parity & & & 0.17 \\
\hline 0 & $33(38.8)$ & $61(48.4)$ & \\
\hline 1 or more & $52(61.2)$ & $65(51.6)$ & \\
\hline Smoking status & & & 0.06 \\
\hline Smoker & $11(12.9)$ & $7(5.6)$ & \\
\hline Nonsmoker & $74(87.1)$ & $119(94.4)$ & \\
\hline Pre-pregnancy BMI, kg/m² & & & $<0.001$ \\
\hline Less than 25 & $26(31.0)$ & $69(55.2)$ & \\
\hline $25-29.9$ & $27(32.1)$ & $37(29.6)$ & \\
\hline 30 or more & $31(36.9)$ & $19(15.2)$ & \\
\hline Season of blood draw & & & 0.33 \\
\hline Winter & $21(25.0)$ & $35(27.8)$ & \\
\hline Spring & $32(38.1)$ & $35(27.8)$ & \\
\hline Summer & $11(13.1)$ & $26(20.6)$ & \\
\hline Fall & $20(23.8)$ & $30(23.8)$ & \\
\hline Latitude of study site & & & 0.06 \\
\hline $40^{\circ} \mathrm{N}$ to $42^{\circ} \mathrm{N}$ & $57(67.1)$ & 99 (78.6) & \\
\hline $30^{\circ} \mathrm{N}$ to $36^{\circ} \mathrm{N}$ & $28(32.9)$ & $27(21.4)$ & \\
\hline Treatment group & & & 0.88 \\
\hline 17a-hydroxyprogesterone caproate & $38(44.7)$ & $55(43.7)$ & \\
\hline Inactive & $47(55.3)$ & $71(56.4)$ & \\
\hline Gestational age at blood draw, wk & $26.2( \pm 1.1)$ & $26.3( \pm 1.2)$ & 0.37 \\
\hline Gestational age at delivery, wk & $34.5( \pm 3.4)$ & $35.7( \pm 2.3)$ & $<0.01$ \\
\hline
\end{tabular}




\begin{tabular}{lccc}
\hline Characteristic & $\begin{array}{c}\text { Less Than } 75 \\
\text { nmol/L } \\
\mathbf{n = 8 5}\end{array}$ & $\begin{array}{c}\mathbf{7 5} \text { nmol/L or } \\
\text { More } \\
\mathbf{n}=\mathbf{1 2 6}\end{array}$ & $\boldsymbol{P}$ \\
\hline Infant birthweight, g & $2056( \pm 535)$ & $2263( \pm 477)$ & $<0.01$ \\
\hline
\end{tabular}

BMI, body mass index.

Data presented as n (\%) or mean ( \pm standard deviation) unless otherwise specified. 
Table 3

Association Between Maternal Serum 25-Hydroxyvitamin D at 24-28 Weeks and Preterm Birth at Less Than 35 Weeks

\begin{tabular}{|c|c|c|c|c|c|}
\hline $\begin{array}{l}\text { Maternal 25- } \\
\text { Hydroxyvitamin D }\end{array}$ & $\begin{array}{c}\text { Preterm } \\
\text { Birth Less } \\
\text { Than 35 } \\
\text { Weeks }\end{array}$ & $\begin{array}{c}\text { Birth } 35 \\
\text { Weeks or } \\
\text { More }\end{array}$ & $\begin{array}{c}\text { Pearson } \\
P\end{array}$ & $\begin{array}{c}\text { Unadjusted OR } \\
(95 \% \mathrm{CI})\end{array}$ & $\begin{array}{l}\text { Adjusted }^{*} \text { OR } \\
\quad(95 \% \mathrm{CI})\end{array}$ \\
\hline Less than $75 \mathrm{nmol} / \mathrm{L}$ & $42(49.4)$ & $43(50.6)$ & & 1.0 (ref) & 1.0 (ref) \\
\hline $75 \mathrm{nmol} / \mathrm{L}$ or more & $33(26.2)$ & $93(73.8)$ & $<0.001$ & $0.4(0.2,0.7)$ & $0.4(0.2,0.8)$ \\
\hline $\begin{array}{l}\text { Per onestandard } \\
\text { deviation increase }{ }^{\dagger} \\
\text { (continuous) }\end{array}$ & $\mathrm{n} / \mathrm{a}$ & $\mathrm{n} / \mathrm{a}$ & & $0.5(0.4,0.7)$ & $0.5(0.3,0.8)$ \\
\hline $\begin{array}{l}\text { Quartile } 1 \text { (median } \\
43.6 \mathrm{nmol} / \mathrm{L})\end{array}$ & $27(51.9)$ & $25(48.1)$ & & 1.0 (ref) & $1.0(\mathrm{ref})$ \\
\hline $\begin{array}{l}\text { Quartile } 2 \text { (median } \\
72.7 \mathrm{nmol} / \mathrm{l})\end{array}$ & $24(45.3)$ & $29(54.7)$ & 0.50 & $0.8(0.4,1.7)$ & $1.0(0.4,2.5)$ \\
\hline $\begin{array}{l}\text { Quartile } 3 \text { (median } \\
95.4 \mathrm{nmol} / \mathrm{L})\end{array}$ & $15(28.3)$ & $38(71.7)$ & 0.01 & $0.4(0.2,0.8)$ & $0.4(0.2,1.1)$ \\
\hline $\begin{array}{l}\text { Quartile } 4 \text { (median } 116 \\
\text { nmol/L) }\end{array}$ & $9(17.0)$ & $44(83.0)$ & $<0.001$ & $0.2(0.1,0.5)$ & $0.2(0.1,0.7)$ \\
\hline
\end{tabular}

OR, odds ratio; CI, confidence interval.

Data are $\mathrm{n}(\%)$ unless otherwise specified.

* Adjusted for maternal race-ethnicity, gestational age at blood draw, study site, parity, prepregnancy BMI, season of blood draw, smoking status, marital status, education, and 17 a-hydroxyprogesterone caproate treatment

${ }^{\dagger}$ One standard deviation is $31.5 \mathrm{nmol} / \mathrm{L}$. 
Table 4

Association Between Maternal Serum 25-Hydroxyvitamin D at 24-28 Weeks and Preterm Birth at Less Than 3 Weeks

\begin{tabular}{|c|c|c|c|c|c|}
\hline $\begin{array}{l}\text { Maternal 25- } \\
\text { Hydroxyvitamin D }\end{array}$ & $\begin{array}{c}\text { Preterm } \\
\text { Birth Less } \\
\text { Than } 32 \\
\text { Weeks }\end{array}$ & $\begin{array}{c}\text { Birth } 32 \\
\text { Weeks or } \\
\text { More }\end{array}$ & $\begin{array}{c}\text { Pearson } \\
P\end{array}$ & $\begin{array}{c}\text { Unadjusted } \\
\text { OR }(95 \% \mathrm{CI})\end{array}$ & $\begin{array}{c}\text { Adjusted }^{*} \\
\text { OR (95\% CI) }\end{array}$ \\
\hline Less than $75 \mathrm{nmol} / \mathrm{L}$ & $16(18.8)$ & $69(81.2)$ & & $1.0(\mathrm{ref})$ & 1.0 (ref) \\
\hline $75 \mathrm{nmol} / \mathrm{L}$ or more & $9(7.1)$ & $117(92.9)$ & 0.01 & $0.3(0.1,0.8)$ & $0.2(0.1,0.6)$ \\
\hline $\begin{array}{l}\text { Per one standard } \\
\text { deviation increase }{ }^{\dagger} \\
\text { (continuous) }\end{array}$ & $\mathrm{n} / \mathrm{a}$ & $\mathrm{n} / \mathrm{a}$ & & $0.6(0.4,0.9)$ & $0.4(0.2,0.8)$ \\
\hline $\begin{array}{l}\text { Quartile } 1 \text { (median } 43.6 \\
\text { nmol/L) }\end{array}$ & $10(19.2)$ & $42(80.8)$ & & $1.0(\mathrm{ref})$ & 1.0 (ref) \\
\hline $\begin{array}{l}\text { Quartile } 2 \text { (median } 72.7 \\
\text { nmol/L) }\end{array}$ & $7(13.2)$ & $46(86.8)$ & 0.40 & $0.6(0.2,1.8)$ & $0.5(0.1,1.7)$ \\
\hline $\begin{array}{l}\text { Quartile } 3 \text { (median } 95.4 \\
\text { nmol/L) }\end{array}$ & $6(11.3)$ & $47(88.7)$ & 0.26 & $0.5(0.2,1.6)$ & $0.4(0.1,1.5)$ \\
\hline $\begin{array}{l}\text { Quartile } 4 \text { (median } 116 \\
\text { nmol/L) }\end{array}$ & $2(3.8)$ & $51(96.2)$ & 0.01 & $0.2(0.03,0.8)$ & $\begin{array}{l}0.1(0.02 \\
\quad 0.7)\end{array}$ \\
\hline
\end{tabular}

OR, odds ratio; CI, confidence interval.

Data are $\mathrm{n}(\%)$ unless otherwise specified.

* Adjusted for maternal race-ethnicity, gestational age at blood draw, study site, parity, pre-pregnancy BMI, season of blood draw, smoking status, marital status, education, and 17 a-hydroxyprogesterone caproate treatment

${ }^{\dagger}$ One standard deviation is $31.5 \mathrm{nmol} / \mathrm{L}$ 